\title{
Hybrids between Bar-headed Goose Anser indicus and Snow Goose Anser caerulescens
}

\author{
Hybrider mellan stripgås Anser indicus och snögås Anser caerulescens
}

JÖRN LEHMHUS \& C. G. GUSTAVSSON

\begin{abstract}
Very few hybrids between Bar-headed Goose Anser indicus and Snow Goose Anser caerulescens have been described in the literature. In this article we give a morphological description of such hybrids, based on 35 individuals which we either observed ourselves or found pictures of on the Internet. Some hybrids were rather similar to Bar-headed Geese and others more closely resembled intermediate phase Snow Geese. General colouration, details and distinguishing features are described in the text together with photos. The yearly numbers of hybrids increased over time. This may be due to an actual

increase in number of individuals, but may also reflect an increased interest in observing and reporting hybrids. Many hybrids were initially reported as something else, and there is therefore presumably under-reporting also in registers without photographs. We hope the information in this article will facilitate correct reporting.

Jörn Lehmhus, Kattenbalken 3, 38162 Cremlingen-Weddel, Germany.E-mail: lehmhus@yahoo.de

C. G. Gustavsson, Box 54, 56821 Skillingaryd, Sweden. E-mail: cg.gustavsson@gmail.com
\end{abstract}

Received 11 November 2013, Accepted 27 June 2014, Editor: J. Waldenström

\section{Introduction}

Hybridization between bird species has been thought to be uncommon, but several publications in the last decades have demonstrated that this is not true (e.g. Grant \& Grant 1992, McCarthy 2006, Randler 2000, 2004, Gillham \& Gillham 1996, 2002, Kampe-Persson \& Lerner 2007). In fact, according to an overview by Grant \& Grant (1992) about every tenth bird species has produced hybrids, and more than $40 \%$ of the species in the order Anseriformes have produced at least one hybrid. The detectability of hybrids differs depending on the species involved and may influence the number of observations of individual hybrid combinations (Randler 2004). Hybrid geese are often not easily identified and may even pass undetected, especially if plumage traits are close to one of the parent species. This applies also to the hybrid combination we intend to discuss in the following.

It is our impression that images of hybrids between Bar-headed Goose Anser indicus and Snow Goose Anser caerulescens have become increasingly common on the Internet over the recent few years. As already indicated, these birds were however often classified as something else, usu- ally as either of the parent species. This points to the problem that the reference literature on this type of hybrid is scarce. The existence of hybrids between Bar-headed Goose and Snow Goose has been reported by some authors (McCarthy 2006, Kampe-Persson \& Lerner 2007, Rowell et al. 2004, International Zoo Yearbook 1970, 1973, 1976 and 1979), but we are aware of only one article which describes a proven hybrid, in that case the female offspring of a male blue phase Snow Goose and a female Bar-headed Goose (Tornelli 1984). That article also includes a black and white photograph of the hybrid.

The aim of this article is to give an overall morphological description of what we consider to be hybrids between Bar-headed Goose and Snow Goose and to compare the number of observations of such birds to some general reporting parameters.

\section{Material and methods}

The material comprises our own observations together with all "presumed" hybrids between Barheaded Goose and Snow Goose which we could find on the Internet. The term "presumed" is here 
used in the sense that there were clear signs of the involvement of both Bar-headed Goose and Snow Goose, but no indication of alternative parent species being involved. The photo archives of Artportalen (http://www.artportalen.se/birds/default. asp, http://www.club300.se/Gallery/Gallery.aspx), Rapporteringssystem for fugler (http://artsobservasjoner.no/fugler), Tarsiger (http://www.tarsiger.com/home/index.php?lang=eng), and Netfugl (http://www.netfugl.dk/pictures.php?) were systematically checked for pictures of such birds under the headings "Hybrids" (any), "Bar-headed Goose", "Snow Goose" and "Oddies".

All 35 birds which we considered to be hybrids between Bar-headed Goose and Snow Goose (and when applicable also the Internet source) are presented in Appendix 1 in a way which will allow the readers to form their own opinions on them and also expand the number of accessible illustrations beyond what can be enclosed in this article.

A number of photographers kindly allowed us to use their photographs. Together with our own pictures these are used to illustrate the typical features of these presumed hybrids between Snow Goose and Bar-headed Goose.

\section{Results}

\section{Description of the hybrids - General colouration}

The colouration and pattern of the presumed hybrids between Bar-headed Goose and Snow Goose is very variable, but in general they exhibit some resemblance to Bar-headed Geese and to so-called blue phase, or intermediate Snow Geese. An example is the hybrid between male blue phase Snow Goose and female Bar-headed Goose from Italy (Tornielli 1984), but as the Snow Goose parent was a blue phase bird this is not surprising. Also, this is a single example and does not describe the full variability. However, there are other birds with extensive white colouration on flanks, neck or scapulars indicating that the Snow Goose involved may have been a white phase bird (Figures 1-5). Nevertheless, these birds still show greyish areas on the body and coloured tertials with some resemblance to the tertials of blue phase Snow Geese (Figures 1-5). This indicates that also hybrids involving white phase Snow Geese may resemble blue phase Snow Geese, a point that will be addressed in the discussion.

\section{Greater coverts and tertials}

Greater coverts and tertials in Bar-headed Geese are broad, straight and uniformly light grey with a thin whitish fringe (Figure 6). In Snow Geese, these feathers are slender and more pointed, the greater coverts also down-curving. In white phase Snow Geese the tertials and greater coverts are allwhite. In blue phase Snow Geese these feathers show a dark, blackish centre and a broad white or grey edge (Figure 7).

Tertials and greater coverts of presumed hybrids between Bar-headed Goose and Snow Goose resemble the tertials and greater coverts of blue phase Snow Goose in pattern and colouration, although the pattern may be slightly more blurred. Greater coverts and tertials both show a broad white or grey fringe and a darker centre in the hybrids, similar to blue phase Snow Geese (Figure 1-5 and 8-14). The dark centre of the greater coverts, and sometimes also the tertials, can be less dark than in blue phase Snow Geese tertials (Figures 1, 4 and 8-9 (the lighter bird in the latter two figures)). Greater coverts and tertials are more slender and more pointed than in Bar-headed Geese, though in many cases still broader than in Snow Geese (Figures 1-3, 5 and 10). Another difference to pure Snow Geese is that in most hybrids the greater coverts are only slightly down-curving, or not down-curving at all (Figures 1-5 and 8-11). But exceptions with strongly down-curving greater coverts are also known to occur (Figure 12).

Mostly the hybrids' tertials and greater coverts are very long (e.g. Figures 1-5 and 12), covering the secondaries and therefore resembling both Snow Geese and Bar-headed Goose in this regard. In a few cases, only the tips of the secondaries may be visible (Figures 8 and 11). In other Anser geese, like Greylag Goose Anser anser or Greater Whitefronted Goose Anser albifrons, the secondaries are less completely covered by the greater coverts.

\section{Scapulars}

In blue phase Snow Geese, scapulars are dark grey and slightly darker towards the tip (Figure 7). In Bar-headed Geese these feathers are light grey with a white edge (Figure 6).

In most hybrids these feathers are intermediate grey, in general lighter than in blue phase Snow Geese and darker than in Bar-headed Geese (Figures 1-5 and 8-11). Unlike blue phase Snow Geese, the scapulars have a pale edge (Figures 1-5 and 8-11), but not always as white as in Bar- 
headed Geese. This results in a more obvious scaly pattern in these hybrids, unlike the more uniformly dark grey blue phase Snow Geese, and the more uniformly pale grey Bar-headed Geese. Very rarely dark birds show no pale edges to the scapulars (Figures 8-9).

\section{Undertail coverts}

In Bar-headed Geese, white phase Snow Geese and also in many blue phase Snow Geese undertail coverts are white, similar to those of other Anser geese except Emperor Goose Anser canagicus. In the hybrids, the undertail coverts are also generally white (Figures 1-5 and 10-12). However, in some blue phase Snow Geese the undertail coverts are dark grey. This is occasionally also found in some dark hybrids (Figure 9), indicating that in such cases the Snow Goose parent most likely was a blue phase bird.

\section{Head and neck pattern}

The typical head and neck pattern of Bar-headed Goose is seen in Figure 6. In white phase Snow Geese, head and neck are all-white, whereas in blue phase Snow Geese dark feathers are found on the neck, sometimes reaching the crown. The amount of dark feathers on head and neck is variable.

The head and neck are all-white in some hybrids like in white phase Snow Geese (Figures 2-3). In others the pattern is close to some blue phase Snow Geese, with some dark feathers on the crown and the hindneck (for example Figures 13 and 17). But there are also birds that show a Bar-headed Gooselike pattern with well developed bars (Figures 5, 8-9 and 16). Several birds have the white stripe typical for Bar-headed Geese running down the sides of the neck (Figures 4-5 and 8-11). In some hybrids the white stripe down the sides of the neck is markedly shortened and does not reach as far down (Figure 12) as in Bar-headed Goose.

\section{Bare parts - bill}

In Bar-headed Geese, the bill is yellowish orange and has a black nail. There is no "grinning patch" (Figure 6). In Snow Geese, the bill is pink and shows a pronounced grinning patch with black cutting edges of the mandibles (Figure 7). Towards the base, the bill of Snow Geese can have a slight orange hue.

In most hybrids, the bill is pale orange or yellow orange, often becoming pinkish towards the tip (Figures 3-5, 8 and 16). A few hybrids have a more orange bill colouration close to that in Barheaded Goose, e.g. the bird in Figures 10 and 17. In many birds no obvious grinning patch is visible (e.g. Figure 18), or only a weak grinning patch can be seen (e.g. Figure 16). Only in a few birds a grinning patch is slightly more pronounced (e.g. Figure 17), but never as pronounced as in Snow Geese. In all birds observed so far, the cutting edges of the mandibles are at least partly black (e.g. Figures 1, $4,9,11-12$ and 16-18), but this is often not visible in birds with closed bills. The nail can be pale as in Snow Goose (Figure 18), black as in Bar-headed Goose (Figure 17) or partly pale and partly black (Figure 16).

\section{Bare parts - legs and feet}

The legs are yellowish orange in Bar-headed Geese and pink in Snow Geese. Depending on light, the leg colour in hybrids may show many shades between the pink of the Snow Goose and the yellowish orange of the Bar-headed Goose (Figures 1-4 and 8). In some hybrids the legs may look more pink than orange (Figure 13), but they can also appear pale orange (Figure 14). There are even hybrids with legs appearing darker and deeper orange than the yellowish orange legs of Bar-headed Goose (Figures 12 and 15).

\section{Numbers of birds}

The hybrids in this material are presented in Appendix 1, which also includes observation date, location, primary classification and Internet addresses of pictures. There has been an increasing number of hybrid pictures during the last two years and when our own observations are added, there was a substantial increase in 2011.

\section{Discussion}

Hybrids between Bar-headed Goose and Snow Goose should be rare according to the literature. McCarthy (2006) gives reference to one bird which reached juvenile age (Steklenev 1993) and to a few reports on breeding in captivity (five more references including Tornielli 1984 and International Zoo Yearbook 1970, 1973, 1976 and 1979). In four articles that count the numbers of goose hybrids, the total numbers of this species combination were estimated to be 1 individual among 210 hybrids in Great Britain 2000 (Rowell et al. 2004) and 1 individual among totally 310-327 hybrids in Sweden 
2005 (Kampe-Persson \& Lerner 2007), whereas two other studies reported no such hybrid in Great Britain 1991 (Delany 1993) and in Germany 1998 (Randler 2000).

The 35 individuals which we have listed in Appendix 1 should therefore be regarded as a large material. Nonetheless, there seem to be additional hybrids which are not photo-documented and/or reported as something else. One indication that under-reporting should be suspected in not photodocumented birds is the rather high rate of initial misclassifications (Appendix 1). This underlines the value of pictures to substantiate field observations.

The number of hybrids included in Appendix 1 increased over time. This may have several reasons, such as that the number of hybrid individuals has increased, but also that the interest to observe and report hybrids may have increased (Randler 1999, Kampe-Persson \& Lerner 2007). The markedly increased number of hybrids in 2011 was largely driven by our own observations.

\section{Comparison with other hybrid geese}

The presumed hybrids between Bar-headed Goose and Snow Goose described here show very high variability in colouration and pattern. Higher variability in hybrids than in the parent species is known also from other goose hybrids, e.g. Greylag Goose with Barnacle Goose Branta leucopsis (Gustavsson 2009), Greylag Goose with Canada Goose Branta canadensis (Lehmhus 2010) and other hybrid Anatidae (e.g. hybrids between two Anas species, (Lehmhus 2011)). In this cross between Bar-headed Goose and Snow Goose, the variability may be further increased due to the fact that the Snow Goose has two colour phases, the blue and the white phase.

The hybrids resemble blue phase Snow Geese, as they have greyish areas on the body and greater coverts, and tertials with a blue phase Snow Goose-like pattern, something that is not present in other geese (except the rare blue phase Ross's Goose Anser rossii) (compare e.g. Madge and Burn 1988). But in several cases extensive areas of white are shown on flanks, belly or back. Such hybrids may well have had a white phase Snow Goose as parent, or a bird that had the alleles for the white phase colouration. Cooke and Coach (1968) studied Snow Goose colour morphs, their interaction and the inheritance of colouration. Mainly assortative mating occurred, but there was the possibility of a white colour phase bird pairing with a blue colour phase phenotype, resulting in intermediate birds showing white areas on the body (Cooke \& Cooch 1968). The same phenomenon occurs also in other hybrids of white phase geese (Snow Geese or Ross's Geese) with none-white geese of the genera Anser and Branta (e.g. Shoffner et al. 1979, and some photos from the web). Such hybrids often show some resemblance to blue phase Snow Geese or intermediate Snow Geese. This indicates that the white colouration seems to be partly overcome by genes for dark colouration from the other species. In Lesser Snow Goose (Anser c. caerulescens), the plumage polymorphism is associated with variation in the melanocortin-1 receptor (MC1R) gene with the degree of melanism correlating to the number of copies of variant MC1R alleles (Mundy et al. 2004). Already Cooke and Coach (1968) and later Mundy et al. (2004) note that there are not only the two phases described as blue and white, but also different intermediate birds with varying amounts of white on the body. The mechanism in hybrids can not be clarified here, but it may be assumed that the general mechanism is similar in other, non polymorphic geese, even though no white variants exist in those. However, this may explain the occurrence of dark feathers in hybrids even if the snow goose involved was a white phase, but not why tertial pattern and greater covert pattern resemble Snow Geese in the hybrids.

Especially tertial pattern and pattern of greater coverts of the hybrids indicate that some information on the pattern of Blue Geese must be present also in white phase birds. The juvenile pattern of tertials and greater coverts of pure white phase Ross's Geese or Snow Geese also suggests this, as it is a pale shadow of the Blue Goose tertial and greater covert pattern (compare e.g. Madge and Burn 1988, Sibley 2003). Tertials and greater coverts of hybrids from a white phase Snow Goose or Ross's Goose with a coloured species often resemble tertials of blue phase geese in that these tertials have white or pale grey edges and a dark centre. Ross's Geese are nearly exclusively white phase birds and the closest relative to Snow Goose. One example of a hybrid expressing a Blue Goose tertial and greater covert pattern is a hybrid of Ross's Goose and Barnacle Goose observed at Cley, England (Figure 19). Another example is a hybridisation of Ross's Goose and Emperor Goose in captivity, described by Shoffner et al. (1979). Those birds also showed a Blue Goose tertial and greater covert pattern and various patches of white over the body. In the authors' experience in crosses of white phase Snow Goose or Ross's Goose with Anser geese, the 
blue phase-like colour pattern in the tertials, and additionally in the greater coverts, is even more marked than in crosses with Branta geese. As the presumed Bar-headed x Snow Goose hybrids also show this pattern with the dark centre and the pale edges in their tertials, it is likely that Snow Goose or Ross's Goose parentage is involved. Many of the hybrids show at least a weak grinning patch and they have some degree of black cutting edges of the mandibles. In our opinion, this only leaves the conclusion that the hybrids involve Snow Goose as one parent.

The Bar-headed Goose influence is also observed in varying combinations with Snow Goose traits, as the detailed descriptions have shown. Apart from the head pattern in some birds, there is the white stripe running down the neck sides, the pale orange tones in bare part colouration and the black bill nail. Bar-headed Goose is the only species showing an orange bill with a black nail. Other Anser geese have either a coloured bill with pale nail, a partially black bill (the Bean Goose Anser fabalis group), or an all black bill (compare e.g. Madge and Burn 1988). Moreover, the coloured feathers of these hybrid birds appear in shades of grey, and are not brownish as most other Anser geese are (compare e.g. Madge and Burn 1988). This is a further indication that Snow Goose (dark grey in the blue phase) and Bar-headed Goose (pale grey) are the parent species.

But sometimes other Anser goose hybrids are observed that clearly also show a Bar-headed Goose parentage by their characteristic head pattern. These hybrids differ from the hybrid type described above in that they never show the rather long, more pointed tertials (resembling those of Snow Geese) and never show white or partially white flanks. One such other hybrid type is described here for comparison. We consider these geese to be probable hybrids between Bar-headed Goose and Greylag Goose. Such birds are darker grey than Bar-headed Geese, but paler and greyer than Greylag Geese. Three different birds presumed to be this cross are shown in Figures 20-22. The leg colour varies from a pinkish orange (Figure 20) to bright orange (Figures 21-22). The bill is orange (Figures 21-22), in some birds changing to a pinkish colouration shortly before the bill tip (Figure 20). The nail is black (Figures 20-22), similar to Bar-headed Geese. The bill is often stronger than in Bar-headed Geese, but not as massive as in Greylag Geese. The head and neck pattern is dark grey, or grey-brown and dirty white, and therefore less bright and less contrasty than in Bar-headed Geese (Figures 20-22).
The front can be white, grey or with mixed whitish and grey feathers. The extension of white onto the neck varies between individuals (Figures 20-22). The forewing is paler than the body colouration, similar to Greylag Geese (Figure 20). The tertials are shaped like in Greylag Geese and Bar-headed Geese and are grey-brown with a thin white edge (Figure 22).

\section{Conservation aspects}

Species of the genus Anser are closely related according to several authors (Gonzalez et al. 2009, Ruokonen et al. 2000). Therefore, even in the wild the occurrence of hybrids in Anser geese is not surprising. Hybrids of the Snow Goose with the closely related Ross's Goose have been observed in the wild and described in detail and mixed pairs have been reported (Trauger et al. 1971). Hybrids of the Bar-headed Goose with grey Anser geese have been occasionally reported from the wild range of the species (Hornskov 2008: http://www.netfugl. dk/trip_reports/asia/OBC2008report_JHornskov. pdf).

Hybrids between Bar-headed Goose and Snow Goose are intrageneric Anser hybrids and should as such be suspected to be fertile. This possibility is supported by the observation in Kiel (Germany) of a pair of one hybrid and one apparently pure Bar-headed Goose accompanied by a third bird (Figures 23-24) which was rather similar to Barheaded Geese, but which still had some features which seemed to be derived from Snow Goose and which therefore was suspected to be a backcross Bar-headed Goose $\times$ (Bar-headed Goose $\times$ Snow Goose). At the same location, also other hybrids occurred which were compatible with what one would expect in trigen hybrids between a Bar-headed Goose $\times$ Snow Goose hybrid and a domestic Swan Goose Anser cygnoides f. domesticus (Lehmhus 2011; http:/www.flickr.com/groups/hybridbirds/ discuss/72157602197084567). Fertility of hybrids between Bar-headed Goose and Snow Goose would also be in line with our observations of other fertile intrageneric Anser goose hybrids, such as Emperor Goose $\times$ blue phase Snow Goose producing backcrosses with Emperor Goose (Figure 25 and Lehmhus J. 2009-2012 (http:/www.flickr.com/ groups/hybridbirds/discuss/72157622611286979) and a fertile presumed Swan Goose Anser cygnoides $\times$ Snow Goose hybrid which had a gosling in pair with a Barnacle Goose (Dreyer \& Gustavsson 2010). A presumed hybrid between Bar-headed Goose and Greylag Goose is also believed to be 

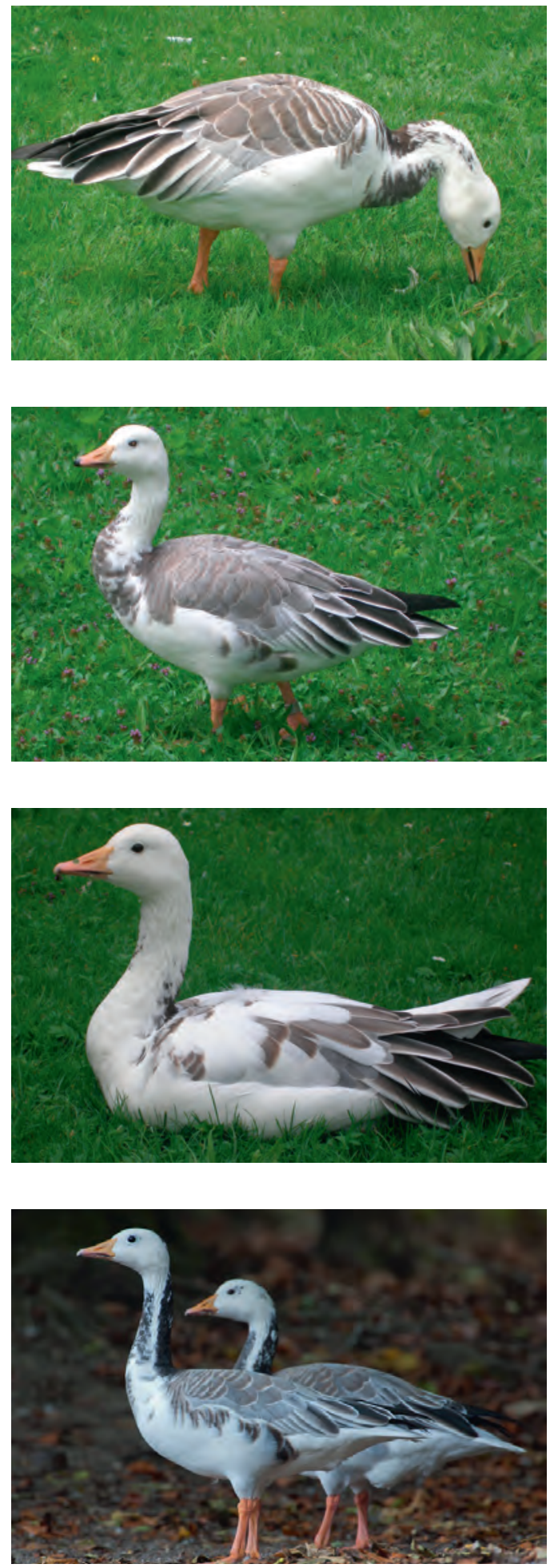

Figure 1. Hybrid between Bar-headed Goose and Snow Goose, in several aspects resembling the blue phase Snow Goose in Figure 7. The grey colouration is darker than in Bar-headed Geese but lighter than in blue phase Snow Geese. The neck has dark and white feathers mixed, except for a stripe of white feathers down the neck at each side. White flanks, indicating the Snow Goose involved was the white phase or an intermediate phase. One partner of pair A. 16 August 2011, Schrevenpark, Kiel, Germany. Photo: Jörn Lehmhus.

Hybrid mellan stripgås och snögås som i flera avseenden påminner om blå morf av snögås. Den grå färgen är mörkare än på stripgås men ändå ljusare än på blå morf av snögås. Halsen har en blandning av mörka och vita fjädrar med undantag för ett stråk av vita fjädrar längs halsens sidor. Vita flanker indikerar att den inblandade snögåsen kan ha varit av vit eller intermediär morf. Ena partnern i par A. 16/8 2011, Schrevenpark, Kiel, Tyskland.

Figure 2. Hybrid between Bar-headed Goose and Snow Goose. The grey colouration is darker than in Bar-headed Goose but still lighter coloured than in blue phase Snow Goose. The bill has a black nail as in Bar-headed Goose and some black on cutting edges of mandibles. The tertials and greater coverts have a pattern resembling those of blue phase Snow Geese, but are broader. White flanks, indicating the Snow Goose involved was the white phase or an intermediate phase. 16 August 2011, Schrevenpark, Kiel, Germany. Photo: Jörn Lehmhus.

Hybrid mellan stripgås och snögås. Den grå färgen är mörkare än hos stripgås men ljusare än hos blå fas av snögås. Näbbnageln är svart som hos stripgås och det finns ett inslag av svart längs näbbkanterna. Tertialer och större täckare påminner om blå fas av snögås, men är bredare. Vita flanker tyder på att snögåsföräldern var av vit eller intermediär fas. 16/8 2011, Schrevenpark, Kiel, Tyskland.

Figure 3. Hybrid between Bar-headed Goose and Snow Goose. This is the whitest of the hybrids in our material and it was part of one of two pairs consisting of two hybrids. At that location alltogether eight hybrids occurred. 16 August 2011, Schrevenpark, Kiel, Germany. Photo: Jörn Lehmhus.

Detta är den vitaste av hybriderna mellan stripgås och snögås $i$ vårt material och den ingick $i$ det andra paret bestående av två hybrider i Kiel, Tyskland. Sammantaget fanns på denna lokal åtta hybrider. $16 / 82011$.

Figure 4. Hybrids between Bar-headed Goose and Snow Goose. Two birds from Bavaria with an appearance closer to Snow Goose at a first glance, but too pale grey and with the white stripe along the sides of the neck which is part of the Bar-headed Goose pattern. 15 November 2011, Stempflesee, Augsburg-Haunstetten, Germany. Photo: Gunter Hasler.

Två hybrider mellan stripgås och snögås från Bayern med utseende närmre snögåsens, men alltför blekgrå och med den vita rand längs halsens sidor, som är en del av stripgåsmönstret. 15/11 2011, Stempflesee, Augsburg-Haunstetten, Tyskland. 
Figure 5. Hybrid between Bar-headed Goose and Snow Goose. Here the head and neck pattern is very Bar-headed Goose-like, but the black stripes are mixed with white feathers. Also the flank is partly white and the tertials and greater coverts resemble a blue phase Snow Goose. 21 March 2010, Rainbow Point, Holt Bay, Blagdon Lake,

Hybrid mellan stripgås och snögås. Huvudets teckning liknar här mycket stripgåsens men de svarta striporna är blandade med vita fjädrar. Flankerna är delvis vita och tertialer och större täckare liknar blå morf av snögås. 21/3 2010, Rainbow Point, Holt Bay, Blagdon Lake, Storbritanien.

Figure 6. Bar-headed Geese, 16 August 2011, Schrevenpark, Kiel, Germany. Photo: Jörn Lehmhus.

Stripgäss, 16/8 2011, Schrevenpark, Kiel, Tyskland. United Kingdom. Photo: Nigel Milbourne.
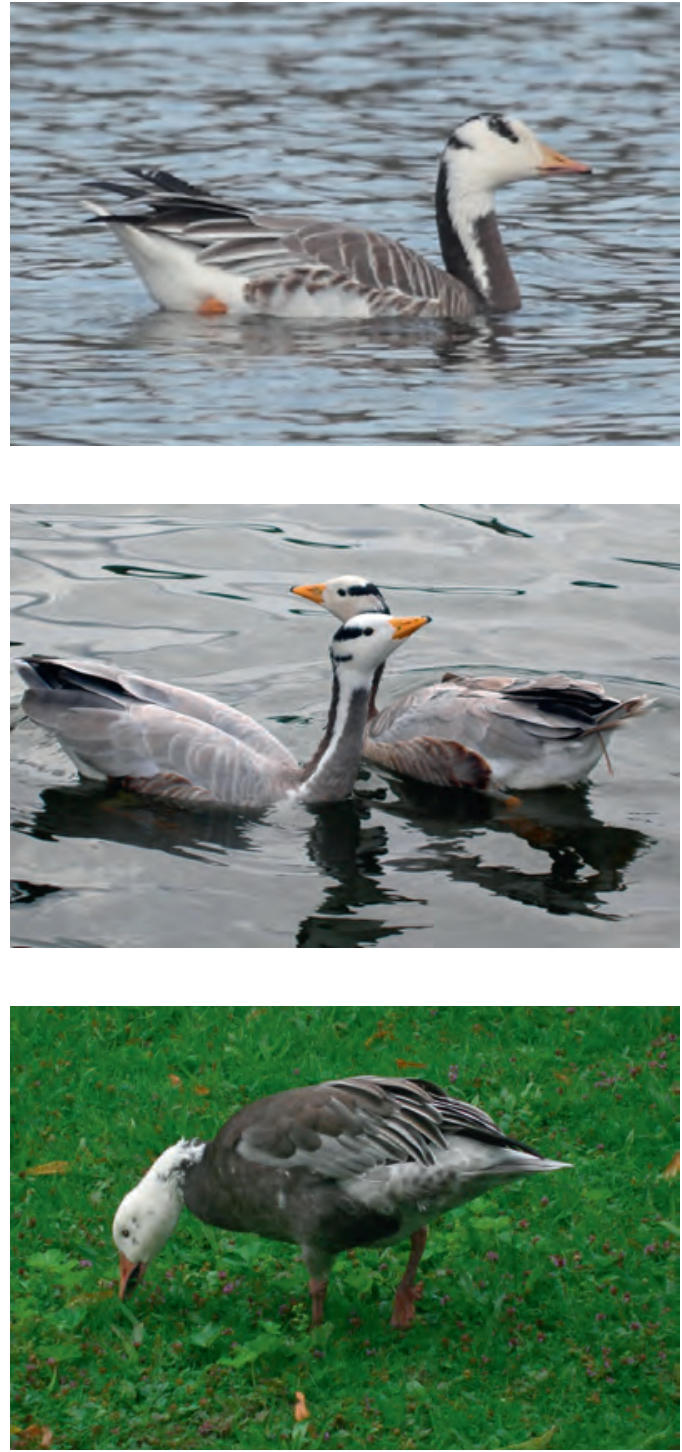

Figure 7. Blue phase Snow Goose, 16 August 2011, Schrevenpark, Kiel, Germany. Photo: Jörn Lehmhus.

Blå morf av snögås, 16/8 2011, Schrevenpark, Kiel, Tyskland.
Figure 8. Two hybrids between Bar-headed Goose and Snow Goose which seem to be pair bonded. One of these is the darkest hybrid in this material, similar in darkness to blue phase Snow Geese. The head of the dark bird is Bar-headed Goose like but with fairly broad bars. The tertials have a blue phase Snow Goose like pattern, but more washed out. The bill colouration and the long white stripe down the sides of the neck indicate Bar-headed Goose genes. 18 March 2012, Weston-in-Gordano, North Somerset, United Kingdom. Photo: Paul Chapman.

Två hybrider mellan stripgås och snögås som verkar ha bildat par. En av dessa är den mörkaste av hybriderna i detta material, lika mörk som blå fas av snögås. Huvudet på den mörka fågeln är stripgåsliknande men med ganska breda stripor. Tertialerna har mönster som hos blå fas av snögås men mera urtvättat. Näbbfärgen och den långa vita randen längs halsens sidor tyder på stripgåsursprung. 18/3 2012, Weston-in-Gordano, North Somerset, Storbritannien.

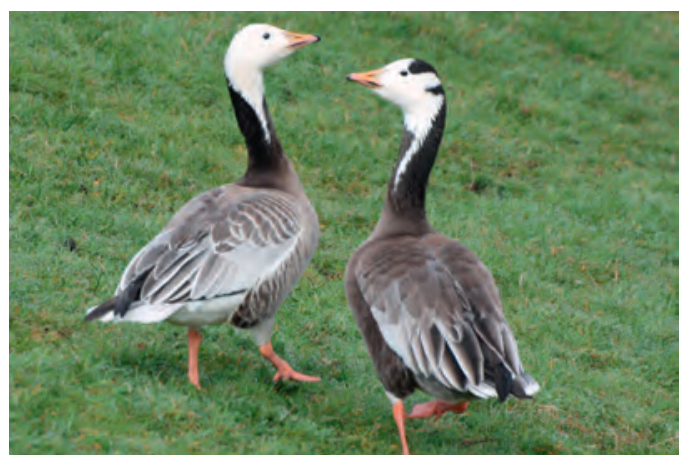



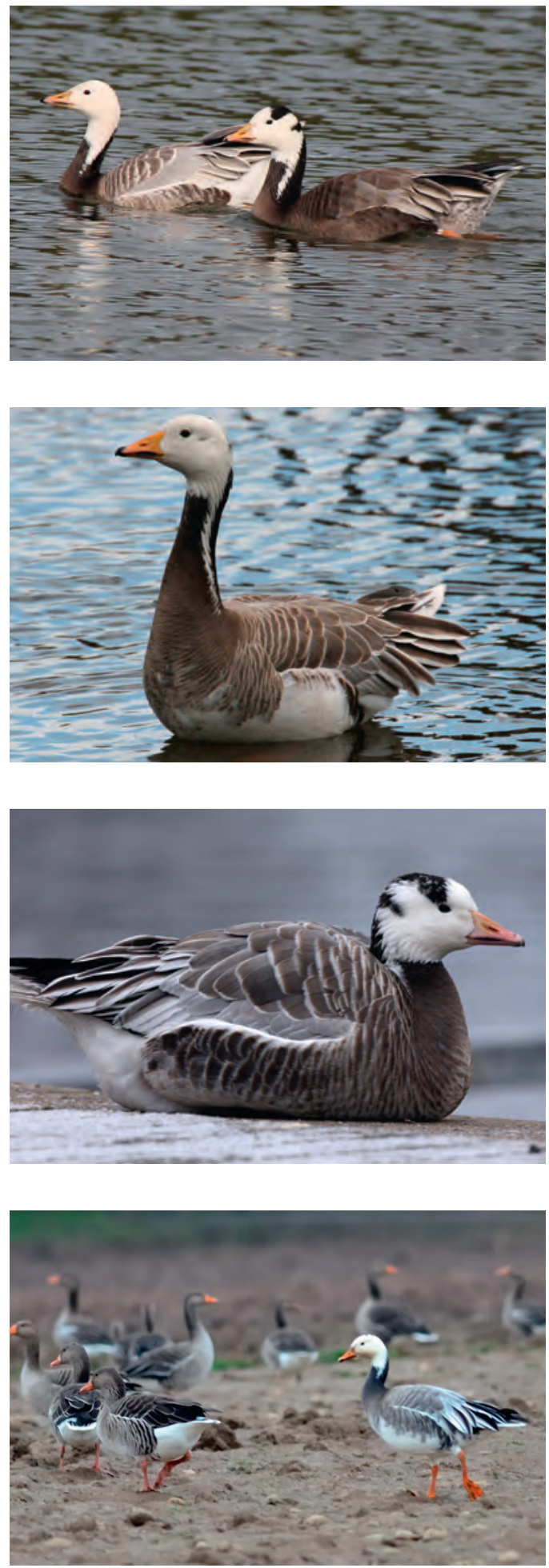

Figure 9. The same two hybrids between Bar-headed Goose and Snow Goose as in Figure 8. The dark hybrid shows grey undertail coverts, a feature only shown in Emperor Goose and in some blue phase Snow Geese. Also this is the only bird in the material without pale trailing edges to the scapulars. 18 March 2012, Weston-in-Gordano, North Somerset, United Kingdom. Photo: Paul Chapman.

Samma två hybrider mellan stripgås och snögås som i Figure 8. Den mörka hybriden har gråa undre stjärttäckare, ett drag som bara ses hos kejsargås och blå fas av snögås. Detta är också den enda fågeln i materialet som inte har ljusa kanter på skapularerna. 18/3 2012, Weston-in-Gordano, North Somerset, Storbritannien.

Figure 10. Hybrid between Bar-headed Goose and Snow Goose. This is a rather dark hybrid but with white flanks. No bars in the head pattern but the white stripe on the neck sides that is typical for Bar-headed Goose. June 2005, Schleswig, Germany. Photo: Sönke Morsch. Hybrid mellan stripgås och snögås. Detta är en ganska mörk hybrid men med vita flanker. Inga stripor på huvudet men det vita stråket på halsens sida är typiskt för stripgås. Juni 2005, Schleswig, Tyskland.

Figure 11. Hybrid between Bar-headed Goose and Snow Goose. One of the darker hybrids in this material. It has from some distance an extremely Bar-headed Goose like head and neck pattern but also tertials with a Snow Goose like pattern and a darker appearance than Barheaded Geese as well as deep orange feet. 26 January 2012, Åhus, Sweden. Photo: Carl Gunnar Gustavsson.

Hybrid mellan stripgås och snögås. En av de mörkaste av hybriderna i detta material. Den har på lite avstånd extremt stripgåsliknande huvud och hals men även tertialer med snögåsliknande mönster och ett mörkare intryck än stripgås samt djupt orange fötter. 26/1 2012, Åhus, Sverige.

Figure 12. This picture shows tertials and greater coverts of a hybrid between Bar-headed Goose and Snow Goose in comparison to those in Greylag Geese. The tertials and greater coverts of this hybrid are strongly curved, very Snow Goose like. In this bird the legs are bright orange. 27 December 2011, Velp, De Bronkhorst, the Netherlands. Photo: André den Ouden.

Denna bild visar tertialer och större täckare på en hybrid mellan stripgås och snögås i jämförelse med dem på grågäss. På denna hybrid är tertialer och större täckare starkt krökta och mycket snögåsliknande. Benen är på denna fågel klart orange. 27/12 2011, Velp, De Bronkhorst, Nederländerna. 
Figure 13. Hybrid between Bar-headed Goose and Snow Goose. The leg colour in this hybrid is clearly pinkish, contrasting with a mainly stetten, Germany. Photo: Gunter Hasler.

Hybrid mellan stripgås och snögås. Benen är på denna hybrid tydligt skära i motsats till den huvudsakligen orange näbben. 15/11 2011, Stempflesee, Augsburg-Haunstetten, Tyskland. pale orange bill. 15 November 2011, Stempflesee, Augsburg-Haun-
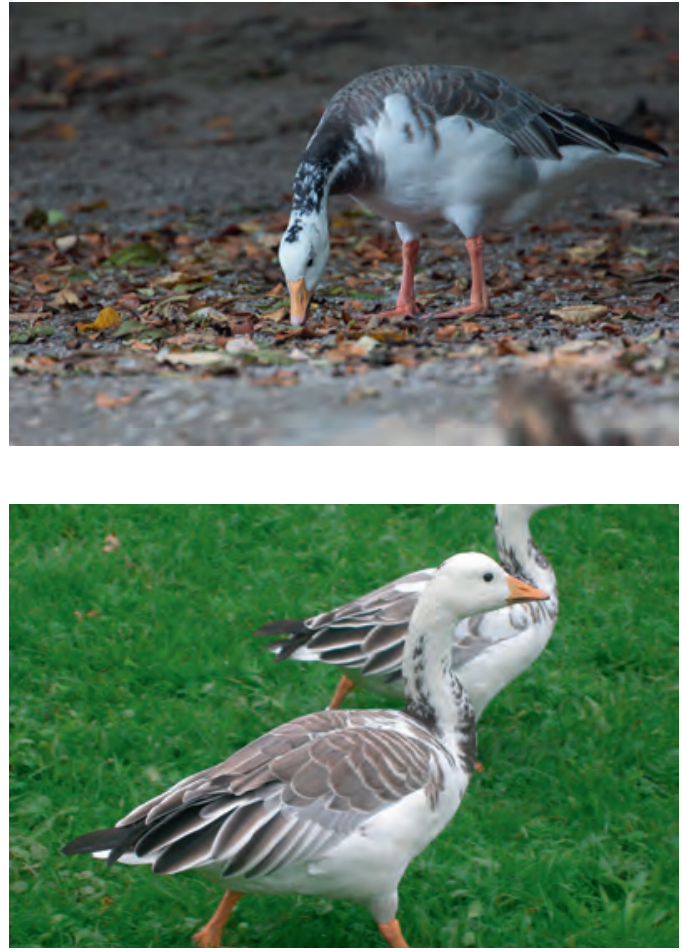

Figure 14. One of the Bar-headed with Snow Goose hybrid pairs. In both birds from this pair legs and bill appear pale pinkish orange. In one bird the nail is pale, in the rear bird the nail is partly black. Tertials and greater coverts are very long with a pattern like blue phase Snow Goose. 16 August 2011, Kiel, Germany. Photo: Jörn Lehmhus. Ett av stripgås-snögås-hybridparen. Båda fåglarna i detta par har blekt rosa-orange ben och näbb. Den ena fägel har blek näbbnagel, den andra (bakre) delvis svart näbbnagel. Tertialer och större täckare är mycket långa med en teckning liknande blå fas av snögås. 16/11 2011, Kiel, Tyskland.

Figure 15. Hybrid between Bar-headed Goose and Snow Goose. The leg colour in this hybrid is rather orange, mallard-like. 24th January Åhus, Sweden. Photo: Carl Gunnar Gustavsson.

Hybrid mellan stripgås och snögås. Benfärgen är på denna hybrid ganska orange och gräsandlik. 24/1 2012, Åhus, Sverige.
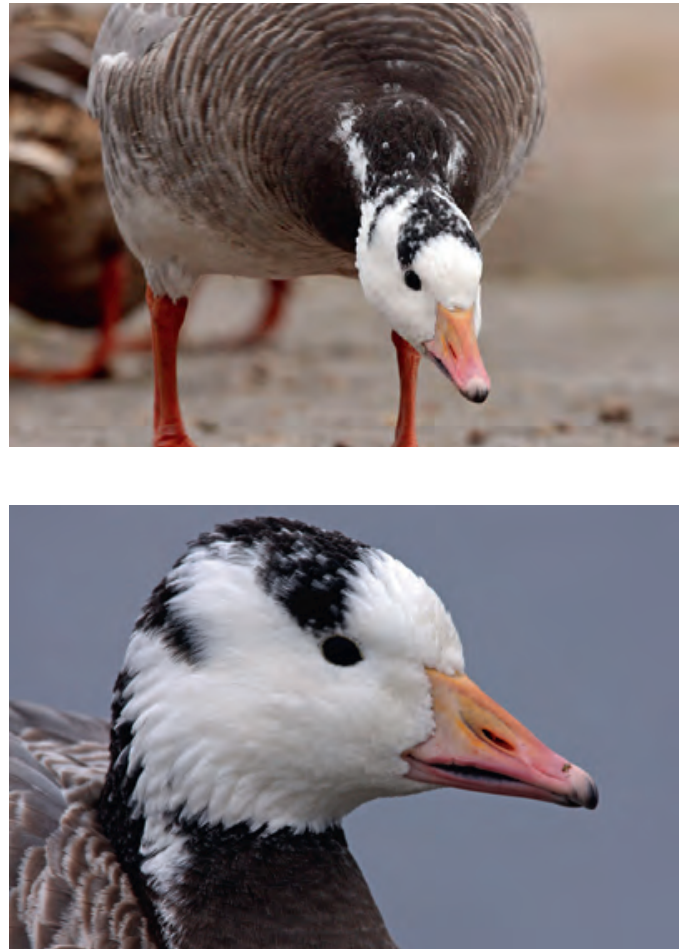

Figure 16. Hybrid between Bar-headed Goose and Snow Goose. The same bird as in Figure 11 and 15 . The bill has a very much reduced grinning patch, but black cutting edges and a partly pale nail as a heritage from the Snow Goose parent. The upper mandible is mainly pale pink, but with a pale yellow orange area around and behind the nostrils. 26 January 2012, Ahus, Sweden. Photo: Carl Gunnar Gustavsson.

Hybrid mellan stripgås och snögås. Samma fågel som på Figure 11 och 15. Näbben har en mycket reducerad "grinning patch" men svarta näbbkanter och delvis blek näbbnagel som arv från snögåsföräldern. Övre näbbhalvan är huvudsakligen rosa men med blekt gulorange område omkring och bakom näsborrarna. 26/1 2012, Åhus, Sverige. 

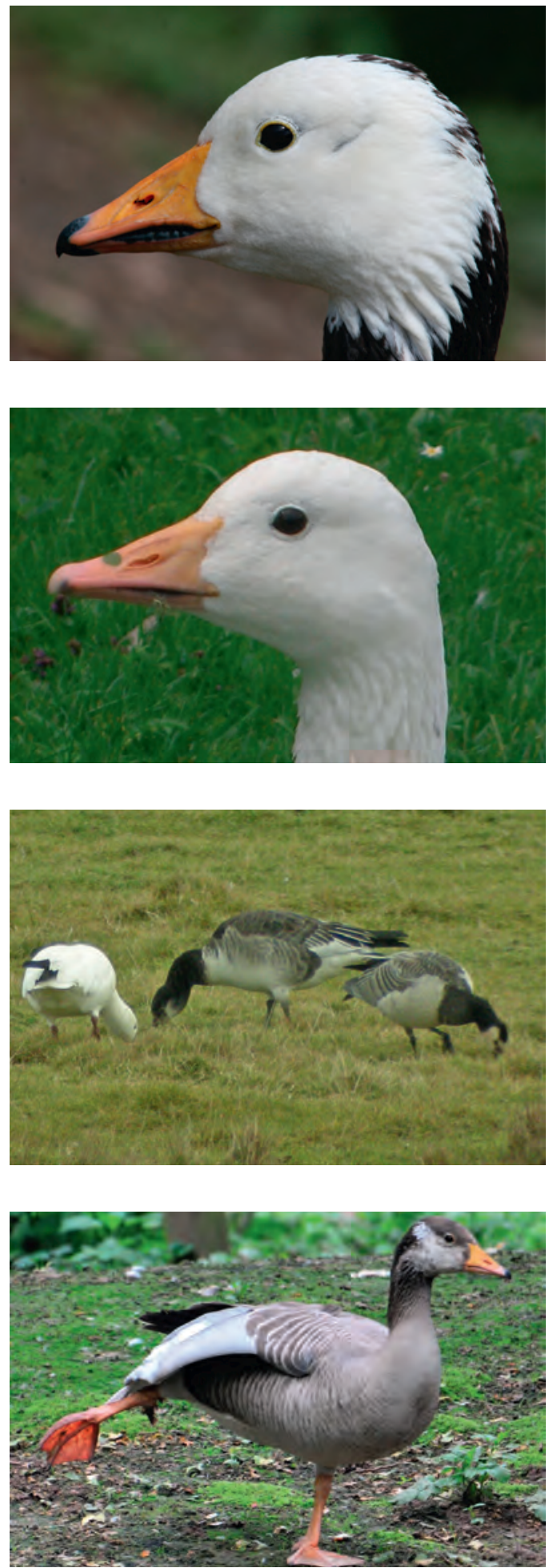

Figure 17. The same hybrid between Bar-headed Goose and Snow Goose as in Figure 10. The bill has a reduced grinning patch and black cutting edges as a heritage from the Snow Goose parent and orange bill and black nail from the Bar-Headed Goose parent. Schleswig, Germany. Photo: Sönke Morsch.

Samma hybrid mellan stripgås och snögås som på Figure 10. Näbben har en reducerad "grinning patch" som arv från snögåsföräldern och näbbkanterna är svarta. Schleswig, Tyskland.

Figure 18. This is the same hybrid between Bar-headed Goose and Snow Goose as in Figure 3. It has no grinning patch, pale nail, but edges of lower and upper mandible show some black. Kiel, Germany, August 2011. Photo: Jörn Lehmhus.

Samma hybrid mellan stripgås och snögås som i Figure 3. Den har ingen "grinning patch", blek näbbnagel men lite svart på näbbkanterna. Kiel, Tyskland, augusti 2011.

Figure 19. Probable hybrid between Ross's Goose and Barnacle Goose with presumed parents. 3 January 2011, Cley, United Kingdom. Photo: Dave Appleton.

Trolig hybrid mellan dvärgsnögås och vitkindad gås med föräldrar. 3/1 2011, Cley, Storbritannien.

Figure 20. For comparison a hybrid between Greylag Goose and Barheaded Goose. Uniform greyish bird with pale forewing as in Greylag Goose and a pattern resembling Bar-headed Goose on head and neck, but grey fronted. 21 May 2009, Darmstadt Vivarium, Germany. Photo: Joachim S. Müller.

För jämförelse en hybrid mellan grågås och stripgås. Jämnt gråaktig fågel med ljus framvinge som på grågås och ett mönster som påminner om stripgås på huvud och hals, men fronten är grå. 21/05 2009, Darmstadt Vivarium, Tyskland. 
Figure 21. For comparison another hybrid between Greylag Goose darker than Bar-headed Goose. Tertials shaped like in Greylag Goose and Bar-headed Goose, grey-brown with a thin white edge. Head and neck pattern resembling Bar-headed Goose. 8 March 2010, Lent, Nijmegen, Netherlands. Photo: Jolanda Wannet.

För jämförelse en annan hybrid mellan grågås och stripgås. Blekt grå med brun anstrykning men klart mörkare än stripgås. Tertialerna formade som hos grågås och stripgås, gråbruna med smal vit kant. Huvud- och halsmönster påminner om stripgås. 8/3 2010, Lent, Nijmegen, Nederländerna. and Bar-headed Goose. Pale grey with brownish tinge, but clearly

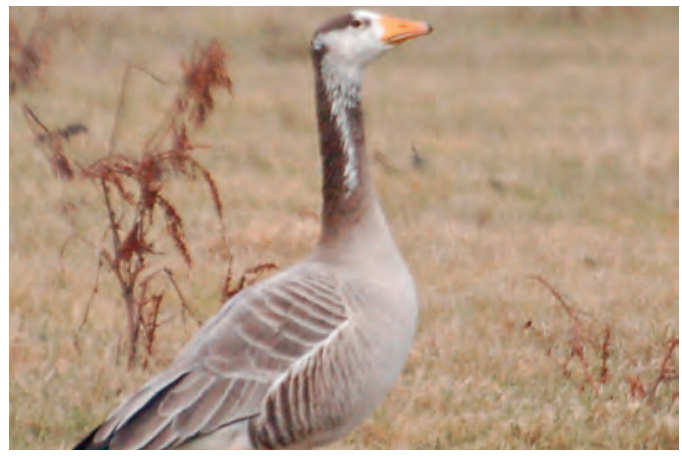

Figure 22. For comparison a third hybrid between Greylag Goose and Bar-headed Goose. Pale grey with slight brownish tinge, but darker than Bar-headed Goose. Tertials shaped like in Greylag Goose and Bar-headed Goose, grey-brown with a thin white edge. Head pattern resembling Bar-headed Goose, but no white stripe running down the sides of the neck. 28 July 2003, Münster, Germany. Drawing: Jörn Lehmhus.

För jämförelse en tredje hybrid mellan grågås och stripgås. Blekt grå med lätt brun anstrykning men mörkare än stripgås. Tertialerna är formade som hos grågås och stripgås, gråbruna med smal vit kant. Huvud- och halsmönster påminner om stripgås, men utan vit rand längs halsens sidor. 28/7 2003, Münster, Tyskland.

Figure 23. Probable backcross (Snow Goose x Bar-headed Goose) $x$ Bar-headed Goose on the right, with its presumed parents, a male Snow Goose x Bar-headed Goose on the left and a female Bar-headed Goose in the middle. The bird is darker than Bar-headed Goose. Tertials are shaped and patterned like the tertials of the hybrid father, but the centre is of the feathers is lighter grey in the backcross. Leg colour deeper orange than in Bar-headed Goose.18 November 2012, Kiel, Germany. Photo: Jörn Lehmhus.

Trolig återkorsning mellan hybrid snögås $x$ stripgås och stripgås till höger, med dess förmodade föräldrar, en hane snögås $x$ stripgås till vänster och hona stripgås i mitten. Denna fågel är mörkare än stripgås. På återkorsnings-exemplaret har tertialerna en form och mönster liknande tertialerna hos hybridfadern, men centrum i fjädrarna är ljusare grå. Benfärgen är djupare orange än på stripgås. 18/11 2012, Kiel, Tyskland.

Figure 24. Probable backcross (Snow Goose x Bar-headed Goose) x Bar-headed Goose. Same bird as in Figure 23. The bird is darker than all Bar-headed Geese at this site. Tertials are shaped like in hybrids Snow Goose x Bar-headed Goose, head and neck pattern close to Bar-headed Goose but the borders between black and white more diffuse and some white feathers in the dark hindneck. Tail partly with wholly white feathers. Legs deeper orange than in Bar-headed Goose. 18 November 2012, Kiel, Germany. Photo: Jörn Lehmhus.

Trolig återkorsning mellan hybrid snögås $x$ stripgås och stripgås. Samma exemplar som på Figure 23. Denna fågel är mörkare än alla stripgäss på lokalen. Tertialerna är formade som på hybrider snögås $x$ stripgås. Huvudets och halsens teckning nära stripgåsens men gränserna mellan svart och vitt är mera diffusa och med en del vita fjädrar på det mörka bakhuvudet. Stjärten har delvis helvita fjädrar. Benen är mörkare orange än på stripgås. 18/11 2012, Kiel, Tyskland.
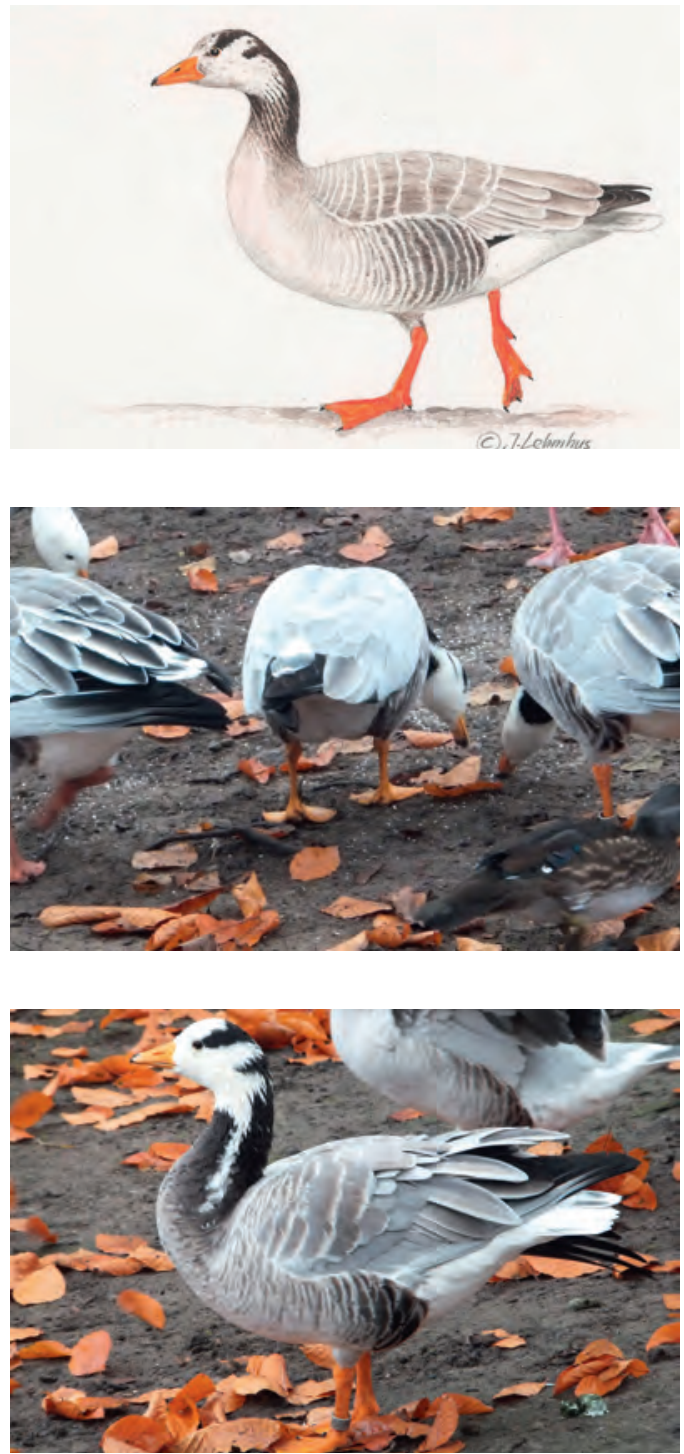


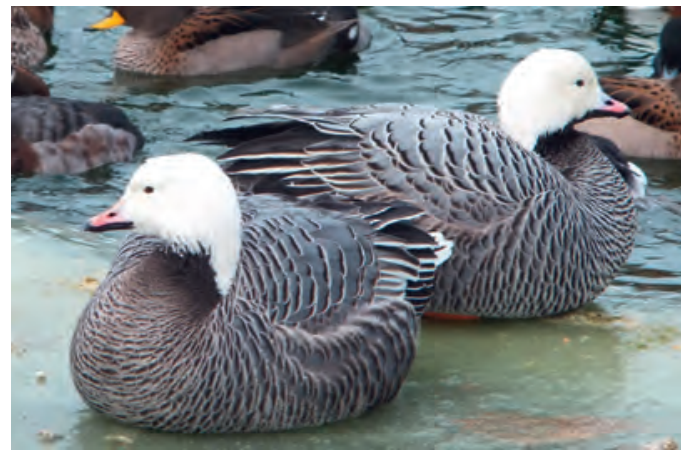

fertile (Reufenheuser 2011 (http://www.flickr.com/ photos/pelikan1939/6821439476). F1 hybrids of Ross's Goose x Emperor Goose were also fertile among themselves and produced an F2 offspring (Shoffner et al. 1979), though fertility of the F1 was reduced. A further example of fertile hybrids between Anser geese comes from domestic geese. The Steinbach Fighting Goose or Steinbacher Goose, a German domestic goose breed, has Chinese Goose (domestic Swan Goose) and domestic Greylag Goose as ancestors (e.g. Schmidt \& Proll 2011). The mixed ancestry is still visible in the unique bill pattern of this breed. Fertility of Lesser White-fronted Goose Anser erythropus $\times$ Greater White-fronted Goose Anser albifrons hybrids has also been proven, though indirectly. Analyses of mtDNA and nuclear microsatellite markers of the captive Lesser White-fronted Goose stock used for reintroduction in Scandinavia revealed that a substantial part of the captive population had a hybrid ancestry with Greater White-fronted Goose (Ruokonen et al. 2007). It was assumed that the hybridisation had occurred in the captive population, as no mtDNA of other goose species was found in samples from wild Lesser White-fronted Geese in the study. But two individuals collected in the wild in wintering areas in England 1936 and in Holland 1966 also proved to be hybrids between Lesser and Greater White-fronted Goose (Nijman et al. 2010). The presence of Greater White-fronted Goose mtDNA haplotypes in Lesser White-fronted Goose could therefore also be a result of naturally occurring hybridisation.

Therefore fertility of Anser sp. $\times$ Anser sp. goose hybrids may be considered relatively common and a potential risk of introgression of genes from these non-native species should be at hand. Such cases are already known from ducks. The most prominent examples are the problem of feral Ruddy
Figure 25. Backcross (Emperor Goose x Blue Snow Goose) x Emperor Goose with its Emperor Goose mother in the background. Only obvious differences to Emperor Goose are the white chin and the slightly down-curved greater coverts in the hybrid. More pictures of the backcross, its siblings and the hybrid father at http://www.flickr. com/groups/hybridbirds/discuss/72157622611286979. Photo: Jörn Lehmhus

Återkorsning mellan hybrid kejsargås x blågås och artren kejsargås med kejsargåsmodern i bakgrunden. De enda uppenbara skillnaderna gentemot kejsargås är den vita kinden och de lätt nedåtböjda större täckarna på hybriden. Fler bilder av återkorsningen, dess syskon och hybridfadern finns på http://www.flickr.com/groups/hybridbirds/ discuss/72157622611286979

Ducks Oxyura jamaicensis producing fertile hybrids with the rare and endangered White-headed Duck Oxyura leucocephala in Spain (MunozFuentes et al. 2007), and the massive introgression of introduced Mallards Anas platyrhynchus into the Pacific Black Duck Anas superciliosa in New Zealand (Gillespie 1985, Rhymer et al. 1994), which threatens this species existence on the island. In Branta geese, apparently fertile hybrids and possible introgression have been observed between the introduced Canada Goose Branta canadensis and the Barnacle Goose Branta leucopsis in Europe (Lehmhus 2010). That could also be relevant to our native Anser species and to the Snow Geese and Bar-headed Geese themselves when they are now beginning to establish wild breeding populations in Europe.

\section{Acknowledgements}

We are indebted to Nigel Milbourne, Paul Chapman, André den Ouden, Jolanda Wannet, Joachim S. Müller, Gunter Hasler, Sönke Morsch and Dave Appleton for the permission to use their photographs in this article, to Lars Leonardson for sending us a large number of pictures of the two geese in Blentarp, Sweden, to be studied in detail and to all those who photographically documented their observations including those listed in Table 1 and thereby allowed us to form a second opinion on the nature of these birds.

\section{References}

Cooke, F. \& Cooch, F.G. 1968. Genetics of Polymorphism in Goose Anser caerulescens. Evolution 22: 289-300.

Delany, S. 1993. Introduced and escaped geese in Britain in summer 1991. British Birds 86: 591-599.

Dreyer, P. \& Gustavsson, C. G. 2010. Photographic documentation of a Swan Goose x Snow Goose Anser cygnoi- 
des x Anser caerulescens hybrid and its offspring with a Barnacle Goose (Branta leucopsis) - a unique three-species cross. Ornithol. Anz. 49: 41-52.

Gillespie, G.D. 1985. Hybridization, Introgression, and morphometric differentiation between Mallards (Anas platyrhynchos) and Grey Duck (Anas superciliosa) in Otago, New Zealand. Auk 102: 459-469.

Gillham, E. \& Gillham, B.L. 1996. Hybrid ducks - A contribution towards an inventory. Gillham, Lydd on Sea, Sussex, UK

Gillham, E. \& Gillham, B.L. 2002. Hybrid ducks - The 5th contribution towards an inventory. Gillham, Lydd on Sea, Sussex, UK

Gonzalez, J., Düttmann, H. \& Wink, M. 2009. Phylogenetic relationships based on two mitochondrial genes and hybridization patterns in Anatidae. Journal of Zoology 279: 310-318.

Grant, P.R. \& Grant, B.R. 1992. Hybridization of bird species. Science 256: 193-197.

Gustavsson, C. G. 2009. Images of Barnacle Goose Branta leucopsis hybrids - a photo documentation of some crosses with different Anser species. Ornis Svecica 19: 19-31.

Hornskov, J. 2008 web. http://www.netfugl.dk/trip_reports/ asia/OBC2008report_JHornskov.pdf

International Zoo Yearbook 1970;10:280-304. DOI: 10.1111/j.1748-1090.1970.tb01333.x

International Zoo Yearbook 1973;13:288-316. DOI: 10.1111/j.1748-1090.1973.tb02182.x

International Zoo Yearbook 1976;16:340-375. DOI: 10.1111/j.1748-1090.1976.tb00200.x

International Zoo Yearbook 1979;19:305-344. DOI: 10.1111/j.1748-1090.1979.tb00590.x

Kampe-Persson, H. \& Lerner, H. 2007. Occurrence of hybrid geese in Sweden - a conservation problem? Ornis Svecica 17: 154-186.

Lehmhus, J. 2009-2012 web: http://www.flickr.com/groups/ hybridbirds/discuss/72157622611286979

Lehmhus, J. 2010. Zur Identifikation einiger häufigerer Gänsehybriden. AVES Braunschweig 1: 25-33.

Lehmhus, J. 2011. Beitrag zur Identifikation von Entenhybriden der Gattung Anas. AVES Braunschweig 2: 21-28.

Lehmhus, J. 2011 web: http://www.flickr.com/groups/hybridbirds/discuss/72157602197084567

Madge, S. \& Burn, H. 1988. Wildfowl. Christopher Helm (Publishers) Ltd, London.

McCarthy, E. M. 2006. Handbook of avian hybrids of the world. Oxford University Press, New York.

Mundy, N.I., Badcock, N.S., Hart, T., et al. 2004. Conserved genetic basis of a quantitative plumage trait involved in mate choice. Science 303: 1870-1873.

Munoz-Fuentes, V.; Vila, C.; Green, A.J.; Negro, J.J.; Sorensen, M.D. 2007. Hybridization between white-headed ducks and introduced ruddy ducks in Spain. Molecular Ecology 16(3): 629-38.

Nijman, V., Aliabadian, M. \& Roselaar, C.S. 2010.Wild hybrids of Lesser White-fronted Goose (Anser erythropus) x Greater White-fronted Goose (A. albifrons) (Aves: Anseriformes) from the European migratory flyway. Zoologischer Anzeiger 248: 265-271.

Randler, C. 1999. Zum Auftreten von Hybriden zwischen Tafel- und Reiherente Aythya ferina $x$ A. fuligula in Deutschland, Österreich und der Schweiz. Vogelwelt 120: 211-220.
Randler, C. 2000. Wasservogelhybriden (Anseriformes) im westlichen Mitteleuropa - Verbreitung, Auftreten und Ursachen. Ökologie der Vögel (Ecology of Birds) 22: 1-106.

Randler, C. 2004. Frequency of bird hybrids: does detectability make all the difference? J. Ornithol. 145: 123-128.

Reufenheuser, J. 2011 web: http://www.flickr.com/photos/ pelikan1939/6821439476

Rhymer, J. M.; Williams, M.J. \& Braun, M.J. 1994. Mitochondrial analysis of gene flow between New Zealand Mallards (Anas platyrhynchos) and Grey Ducks (A. superciliosa). Auk lll(4):970-978.

Rowell, H. E., Ward, R. M., Hall, C. \& Cranswick, P. A. 2004. The Naturalised Goose Survey 2000. The Wildfowl \& Wetlands Trust, Slimbridge.

Ruokonen, M., Kvist, L. \& Lumme, J. 2000. Close relatedness between mitochondrial DNA from seven Anser goose species. J. Evol. Biol. 13: 532-540.

Ruokonen, M., Andersson, A.-C. \& Tegelström, H. 2007. Using historical captive stocks in conservation. The case of the lesser white-fronted goose. Conserv. Genet. 8: 197-207.

Schmidt, H. \& Proll, R. 2011. Rassegeflügel kompakt. Verlag Eugen Ulmer, Stuttgart, Germany.

Shoffner, R. N., Wang, N., Lee, F., King, R. \& Otis, J. S. 1979. Chromosome homology between the Ross's and the Emperor goose. The Journal of Heredity 70: 395-400.

Sibley, D. 2003. Field Guide to the birds of Western North America. Christopher Helm, London.

Steklenev, E. P. 1993. Distant hybridization of some species from the family Anatidae. Cytology and Genetics 23: 22-27.

Tornelli, A. 1984. Ibrido di Oca delle nevi, Anser caerulescens, x Oca indiana, Anser indicus. Riv. ital. Orn., Milano 54: 89-90.

Trauger, D.L., Dzubin, A. \& Ryder, J.P. 1971. White geese intermediate between Ross' Geese and Lesser Snow Geese. Auk 88: 856-875.

\section{Sammanfattning}

Bilder av hybrider mellan stripgås och snögås verkar bli allt vanligare på Internet, men fåglarna är ofta felklassificerade, i regel som endera föräldraarten. Detta kan delvis bero på att det finns så få referensartiklar om denna hybridtyp. Att hybrider mellan stripgås och snögås existerar har rapporterats av några författare (McCarthy 2006, KampePersson \& Lerner 2007, Rowell et al. 2004, International Zoo Yearbook 1970, 1973, 1976 och 1979) men vi känner bara till en enda artikel som beskriver en bevisad hybrid, i det fallet en honfågelavkomma till en blågåshane (blå fas av snögås) och en stripgåshona (Tornelli 1984). Den artikeln innehåller också ett svartvitt foto av hybriden.

Målet med vår artikel här är att ge en generell morfologisk beskrivning av vad vi uppfattar vara hybrider mellan stripgås och snögås samt att redovisa hur antalet inkluderade observationer utvecklats över tid. 


\section{Material och metoder}

Materialet omfattar våra egna observationer tillsammans med alla fåglar vi kunde hitta på Internet, där det fanns klara hållpunkter för hybrid med inblandning av både stripgås och snögås men inga tecken på alternativa föräldraarter. Vi fann 35 sådana exemplar, som presenteras i Appendix 1 på ett sätt som låter läsaren bilda sig en egen uppfattning och även utvidga antalet tillgängliga illustrationer utöver vad som innefattas i denna artikel.

Ett antal fotografer lät oss vänligen använda deras fotografier (se Acknowledgements). Tillsammans med våra egna bilder användes dessa för att illustrera de typiska aspekterna hos de förmodade hybriderna mellan snögås och stripgås.

\section{Beskrivning av hybriderna}

Hybriderna varierar i färg och teckning men har viss likhet med både stripgås och blågås. Det finns exemplar med utbredd vit teckning på flanker, hals eller skuldror som tyder på att snögåsföräldern kan ha varit av vit fas (Figur 1-5). Men samma fåglar har även gråa områden på kroppen och färgade tertialer som har viss likhet med tertialerna hos blågås (Figur 1-5). Vi tolkar detta som att även hybrider med vit fas av snögås kan visa likheter med den blå fasen.

\section{Större täckare och tertialer}

De större täckarna och tertialerna är på stripgås breda, raka och jämnt ljusgrå med en smal vitaktig kant (Figur 6) och på snögås smala och mera tillspetsade, de större täckarna också nedåtböjda. På vit snögås är tertialer och större täckare helvita och på blågås har de ett nästan svart mittparti och bred vit eller grå kant (Figur 7).

På hybriderna har de större täckarna och tertialerna en bred vit eller grå periferi och ett mörkare centralparti - de liknar blågåsens (Figur 1-5 och 8-14) fast teckningen kan vara lite suddigare och det mörka centralpartiet på de större täckarna och ibland även tertialerna kan vara mindre mörkt än hos blågås (Figur 1, 4 och 8-9 (den ljusare fågeln i de två senare figurerna)). Större täckare och tertialer är på hybriderna smalare och spetsigare än på stripgås men i många fall ändå bredare än på snögås (Figur 1-3, 5 och 10). En annan skillnad gentemot rena snögäss är att på de flesta hybriderna är de större täckarna bara lätt eller inte alls nedåtböjda (Figur 1-5 och 8-11), men det finns undantag med starkt nedåtböjda större täckare (Figur 12).

Oftast är hybridernas tertialer och större täckare mycket långa (e.g. Figur 1-5 och 12) och täcker armpennorna - de liknar därmed både snögås och stripgås i detta avseende. I några fall kan spetsarna på armpennorna vara synliga i vissa situationer (Figur 8 och 11). På andra Anser gäss som t ex grågås och bläsgås, täcks armpennorna i mindre grad av de större täckarna.

\section{Skapularer (skulderfjädrar)}

Skapularerna är på blågås mörkt grå och t o m antytt mörkare mot spetsen (Figur 7) och på stripgås ljusgrå med vit kant (Figur 6). På flertalet hybrider är dessa fjädrar mellangrå, i regel ljusare än på blågås men mörkare än på stripgås (Figur 1-5 och 8-11). Till skillnad mot blågås har hybridernas skapularer blek kant (Figur 1-5 och 8-11), fast inte alltid lika vit som hos stripgås. Detta medför en mera tydligt fjällig teckning hos hybriderna jämfört med den mera jämnmörka blågåsen och den mera jämnt ljusgrå stripgåsen. I enstaka fall kan mörka hybrider sakna de ljusa kanterna på skapularerna (Figur 8-9).

\section{Undre stjärttäckare}

På stripgås, vit snögås och även många blågäss är de undre stjärttäckarna vita, i likhet med de flesta Anser gåsarterna med undantag för kejsargås. Även på hybriderna är de undre stjärttäckarna i regel vita (Figur 1-5 och 10-12). Men en del blågäss har istället mörkgrå undre stjärttäckare och detta kan någon gång ses även på mörka hybrider (Figur 9). Vi tolkar detta som att snögåsföräldern i dessa fall bör ha varit av blå fas (blågås).

\section{Näbb och ben}

På stripgås är näbb och ben gulaktigt orange, näbbnageln svart och näbben har ingen "grinning patch" (Figur 6). På snögås är näbb och ben rosa och näbben har den artkaraktäristiska "leende" form som kallas "grinning patch", med svarta kanter på båda näbbhalvorna (Figur 7). Mot basen kan snögåsens näbb även ha en lätt orange anstrykning.

På hybriderna varierar benens färg (Figur 1-2, 4, 8, 12-15) och kan på en del exemplar verka mer rosa än orange (Figur 13), men på andra exemplar verka blekorange (Figur 14). Det finns även hybrider vars ben verkar vara mörkare och djupare orange än de gulaktigt orange benen hos stripgås (Figur 12 och 15). Näbben är hos de flesta hybriderna blekorange eller gulorange och blir ofta rosa ut mot näbbspetsen (Figur 3-5, 8 och 16). Ett mindre antal hybrider har en mer orange näbbfärg som ligger nära den hos stripgås, $t$ ex fågeln på Figur 10 och 17. På många fåglar ses ingen tydlig "grinning patch” (t ex Figur 18) eller bara en svag sådan (t 
ex Figur 16). Bara enstaka fåglar har en tydligare "grinning patch" (t ex Figur 17), men aldrig lika uttalad som hos snögås. På alla fåglar vi sett hittills har näbbens kanter på näbbhalvorna varit åtminstone delvis svarta (t ex Figur 1, 4, 9, 11-12, 16-18), men detta kan vara svårt att se på fåglar med sluten näbb. Näbbnageln kan vara blek som på snögås (Figur 18), svart som på stripgås (Figur 17) eller blandat ljus och svart (Figur 16).

\section{Huvud och hals}

Den typiska teckningen på stripgåsens huvud och hals kan ses i Figur 6. Hos snögås har den vita fasen helvitt huvud och hals medan blågåsen har mörka fjädrar på halsen och ibland även på huvudet. Mängden mörka fjädrar på huvud och hals varierar.

Bland hybriderna har en del individer helvitt huvud och hals som hos vit snögås (Figur 2-3). På andra ligger teckningen närmre blågåsens, med en del mörka fjädrar på huvud och nacke (exempelvis Figur 13 och 17). Men det finns också fåglar som visar ett stripgåsliknande mönster med väl utvecklade tvärgående stripor (Figur 5, 8-9 och 16). Många hybrider har den för stripgåsen typiska vita randen längs halsens sidor (Figur 4-5 och 8-11) men på en del av dem är denna rand tydligt förkortad och räcker inte lika långt ner som på stripgås (Figur 12).

\section{Antalet hybrider}

Hybriderna i materialet redovisas i Appendix 1, som innehåller observationsdatum, lokaler, primär klassifikation och Internetadresser till bilder av fåglarna. Antalet fotograferade hybrider mellan stripgås och snögås har således ökat under de senaste åren och när man adderar våra egna observationer märks en påtaglig ökning under 2011. Detta kan tala för att hybrider mellan stripgås och snögås har blivit vanligare, men det kan finnas andra bidragande förklaringar.

\section{Diskussion}

Hybrider mellan stripgås och snögås borde enligt litteraturen vara sällsynta. McCarthy's referenssamling (2006) hänvisar till ett exemplar som nådde juvenil ålder (Steklenev 1993) och till några rapporter om häckningar i fångenskap (ytterligare fem referenser inklusive Tornielli 1984 och International Zoo Yearbook 1970, 1973, 1976 och 1979). Fyra artiklar som räknat antal gåshybrider redovisar bara en stripgås $\mathrm{x}$ snögås bland 210 hybrider i Storbritannien 2000 (Rowell et al. 2004) och en stripgås x snögås bland 310-327 hybrider i Sverige 2005 (Kampe-Persson \& Lerner 2007) medan två andra studier inte rapporterar någon enda sådan hybrid i Storbritannien 1991 (Delany 1993) eller i Tyskland 1998 (Randler 2000).

De totalt 35 individerna som ligger till grund för den här artikeln bör därför ses som ett stort material. Ändå verkar det finnas fler hybrider som inte fotodokumenterats och som rapporterats som något annat. Ett tecken på detta är den ganska höga andelen initiala felklassificeringar i Appendix 1, vilket understryker värdet av att man till rapporter även bifogar bilder.

Appendix 1 visar hur antalet hybrider i vårt material har ökat under de senaste åren, i enlighet med vårt ursprungliga intryck. Detta kan bero på att antalet hybrider verkligen har ökat, men också ha andra orsaker som exempelvis att intresset att observera och rapportera hybrider har ökat (Randler 1999, Kampe-Persson \& Lerner 2007).

Morfologisk jämförelse med några andra gåshybrider

Hybriderna mellan stripgås och snögås uppvisar stor variation i färg och teckning. Högre variation mellan hybrider än hos föräldraarterna är känt också från andra gåshybrider t ex grågås $\mathrm{x}$ vitkindad gås (Gustavsson 2009), grågås x kanadagås (Lehmhus 2010) och andra Anatidae-hybrider (till exempel hybrider mellan två Anas arter (Lehmhus 2011)). I den här korsningen mellan stripgås och snögås kan variationen öka ytterligare genom att snögåsen har två faser, den blå och den vita fasen.

Hybriderna påminner om den blå fasen av snögås (blågås) genom att de har gråa områden på kroppen och genom att större täckare och tertialer har en blågås-liknande teckning, något som inte ses hos andra gåsarter förutom den sällsynta blå fasen av dvärgsnögås (jämför med t ex Madge och Burn 1988). Men många hybrider har utbredda vita områden på flanker, buk och rygg. Dessa kan mycket väl ha en vit snögås som förälder. Samma fenomen dyker upp också på intermediär fas av snögås, som har ett anlag för vit och ett anlag för blå fas, men även på andra hybrider mellan vit fas av snögås eller dvärgsnögås och icke-vita gäss av genera Anser och Branta. Dessa visar också ofta viss likhet med blågås eller intermediär fas av snögås. Särskilt teckningen hos tertialer och större täckare tyder på att någon form av information om teckningen hos den blå fasen av snögås verkar finnas även hos den vita fasen, något som för övrigt även ses på $1 \mathrm{k}$-fåglar av den vita fasen. Tertialer och större täckare hos hybrider mellan vit fas av snögås eller dvärgsnö- 
gås och färgade arter liknar ofta tertialerna hos den blå fasen genom att dessa har vita eller blekgråa kanter och mörkt centrum. Dvärgsnögäss är nästan uteslutande av vit fas och närmast släkt med snögäss. Ett exempel på en hybrid som uttrycker blå fas-liknande teckning på tertialer och större täckare är en hybrid mellan dvärgsnögås och vitkindad gås från Cley i England (Figur 19). Ett annat exempel är de hybrider mellan dvärgsnögås och kejsargås i fångenskap som beskrivits av Shoffner et al. (1979) - de hade också blågås-liknande teckning på tertialer och större täckare samt vita fläckar på kroppen. Eftersom de förmodade hybriderna mellan stripgås och snögås också visar denna typ av teckning med mörkt centrum och bleka kanter på tertialerna anser vi att detta är ett tecken på att snögås (eller dvärgsnögås) verkligen är inblandad.

Många av hybriderna uppvisar åtminstone en svag "grinning patch" och svarta näbbkanter. Detta visar att den ena föräldraarten rimligen är snögås. Påverkan av stripgås ses i varierande omfattning tillsammans med drag av snögås, som detaljbeskrivningarna visar. Frånsett den stripgåsliknande teckningen på huvudet hos vissa fåglar kan man se en vit rand längs halsens sidor, blekorange färgtoner på näbb och ben och svart näbbnagel. Stripgåsen är den enda gåsart som har orange näbb med svart näbbnagel. Andra Anser gäss har antingen färgad näbb med blek näbbnagel, delvis svart näbb (sädgås-gruppen) eller helsvart näbb (se t ex Madge och Burn 1988). Vidare visar de färgade fjädrarna hos hybriderna olika grader av grått men de är inte brunaktiga som hos de flesta andra Anser gässen (se t ex Madge och Burn 1988). Detta är ytterligare ett tecken på att snögås (mörkt grå hos den blåa fasen) och stripgås (blekgrå) är föräldraarterna.

Ibland ser man andra Anser-gås-hybrider vars huvuden har en teckning som tyder på stripgås-inblandning, men de skiljer sig från hybriderna med snögås genom att de enligt vår erfarenhet aldrig har dessas snögåsliknande ganska långa och mera tillspetsade tertialer och inte heller har vita eller delvis vita flanker. För jämförelse beskriver vi här en sådan hybridtyp, som vi uppfattar som hybrider mellan stripgås och grågås. Dessa fåglar är mörkare grå än stripgäss och gråare än grågäss. Tre olika exemplar visas i Figur 20-22. Benens färg varierar mellan rosa-orange (Figur 20) och ljust orange (Figur 21-22). Näbben är orange (Figur 21-22), på en del exemplar övergående till rosa kort före näbbspetsen (Figur 20). Näbbnageln är svart (Figur 20-22) som hos stripgås. Näbben är ofta kraftigare än hos stripgäss men inte lika massiv som på grågäss. Huvud och hals är mörkt grå eller grå-bruna och smutsgrå och därför mindre ljusa och mindre kontrastrika jämfört med stripgäss (Figur 20-22). Fronten kan vara vit, grå eller med blandning av vita och gråa fjädrar. Utbredningen av vitt på halsen varierar mellan olika individer. Framvingen är blekare än kroppen, liksom hos grågäss (Figur 20). Tertialerna har samma form som hos grågäss och stripgäss och är gråbruna med smal vit kant (Figur 22).

\section{Artbevarandeaspekter}

Hybrider mellan stripgås och snögås är intrageneriska hybrider och bör som sådana misstänkas vara fertila. Den möjligheten stöds av observationen i Kiel av ett par bestående av en hybrid och en till synes artren stripgås åtföljda av en tredje fågel (Figur 23-24) som var ganska lik en stripgås men ändå hade vissa drag som verkade härstamma från snögås och som därför misstänktes vara en återkorsning mellan en stripgås-snögås-hybrid och en stripgås. På samma lokal fanns också fåglar som uppfattades som trigena hybrider mellan en stripgås-snögås-hybrid och en knölgås (Lehmhus 2011 (http://www.flickr.com/groups/hybridbirds/ discuss/72157602197084567). Fertilitet hos hybrider mellan stripgås och snögås skulle också vara i överensstämmelse med våra iakttagelser av andra fertila intrageneriska Anser gås hybrider som kejsargås x blågås med återkorsningar med kejsargås (Figur 25 och Lehmhus J. 2009-2012 (www) http://www.flickr.com/groups/hybridbirds/discuss/72157622611286979) och en fertil svangåssnögås-hybrid som fick en gässling i par med en vitkindad gås (Dreyer \& Gustavsson 2010). En förmodad hybrid mellan stripgås och grågås verkade också vara fertil (Reufenheuser 2011 (http://www. flickr.com/photos/pelikan1939/6821439476). F1hybrider mellan dvärgsnögås och kejsargås var likaså fertila mellan varandra och producerade en F2-hybrid (Shoffner et al. 1979), men fertiliteten var reducerad hos F1-generationen. Ännu ett exempel på fertila hybrider mellan Anser gäss kommer från tamgässen. Steinbach Fighting Goose eller Steinbachergåsen är en tysk tamgåssort som härstammar från både knölgås och tamvarianter av grågås (Schmidt \& Proll 2011). Den blandade härstamningen syns på den unika näbbteckningen. Fertilitet hos hybrider mellan olika Anser arter får därför anses vara ganska vanlig och en potentiell risk för introgression av gener från sådana främmande gåsarter föreligger. Detta kan vara relevant för våra inhemska Anser arter men även för snögås och stripgås när dessa arter nu börjar etablera vildhäckande populationer i Europa. 


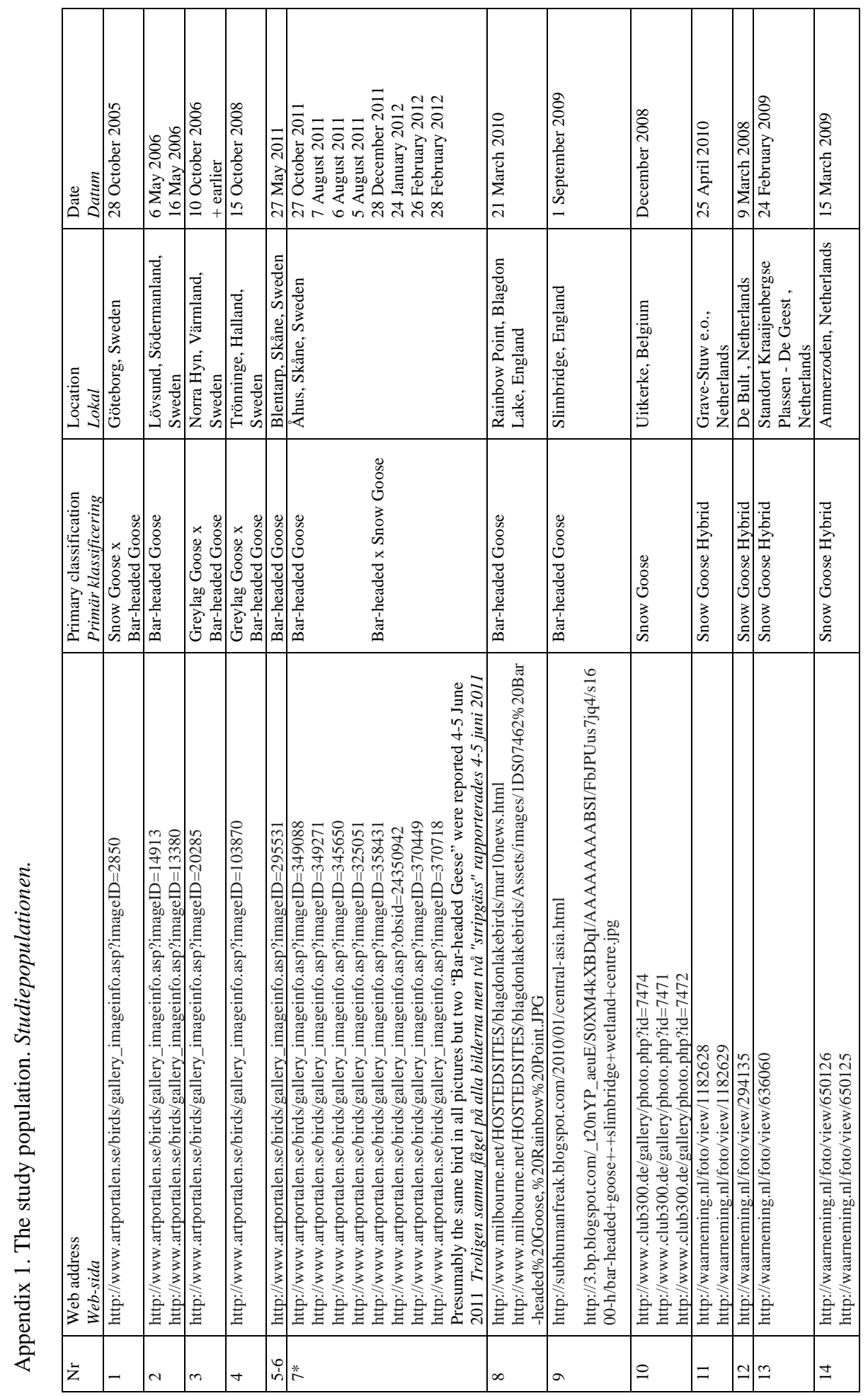

